\title{
Social Sustainability in the Planning, Design, and Construction in Developing Countries: Guidelines and Feasibility for México
}

\author{
Rosy A. Arcila Novelo ${ }^{1, *}$, Sergio O. Álvarez Romero ${ }^{1}$, Gilberto A. Corona Suárez ${ }^{1}$, \\ J. Diego Morales Ramírez ${ }^{2}$ \\ ${ }^{1}$ Faculty of Engineering, Universidad Autónoma de Yucatán, Mérida, Yucatán, México \\ ${ }^{2}$ Faculty of Architecture, Universidad Nacional Autónoma de México, México City, México
}

Received October 5, 2020; Revised April 21, 2021; Accepted May 16, 2021

\section{Cite This Paper in the following Citation Styles}

(a): [1] Rosy A. Arcila Novelo, Sergio O. Álvarez Romero, Gilberto A. Corona Suárez, J. Diego Morales Ramírez, "Social Sustainability in the Planning, Design, and Construction in Developing Countries: Guidelines and Feasibility for México," Civil Engineering and Architecture, Vol. 9, No. 4, pp. 1075-1083, 2021. DOI: 10.13189/cea.2021.090410.

(b): Rosy A. Arcila Novelo, Sergio O. Álvarez Romero, Gilberto A. Corona Suárez, J. Diego Morales Ramírez (2021). Social Sustainability in the Planning, Design, and Construction in Developing Countries: Guidelines and Feasibility for México. Civil Engineering and Architecture, 9(4), 1075-1083. DOI: 10.13189/cea.2021.090410.

Copyright $(2021$ by authors, all rights reserved. Authors agree that this article remains permanently open access under the terms of the Creative Commons Attribution License 4.0 International License

\begin{abstract}
Sustainability is based on three pillars: social, economic, and environmental. However, the main systems of evaluation of the sustainable building, such as Building Research Establishment Assessment Method (BREEAM) and Leadership in Energy and Environmental Design (LEED), have a strong burden towards the environmental aspect, neglecting the social and economic, and underestimating the effects of the building projects on reducing poverty and inequity. The purpose of this research was to identify socioeconomic criteria for the reality of developing countries, specifically México, and systematize them in a conceptual framework for the stages of planning, design, and construction of buildings with a focus on Sustainable Development Goals (SDGs) and human rights. Through semi-structured interviews with experts and surveys, 12 criteria were identified and ranked for the planning stage, 19 for the design stage, and 15 for the construction stage, being especially relevant the contribution to the Sustainable cities and communities (SDG11), Decent work and economic growth (SDG8) and Reduced inequalities (SDG10) goals. It was found that projects considered sustainable were required to have clear policies on the issues of labor rights, social inclusion, zero tolerance for corruption, gender perspective, and prevention of damage to community environmental assets. The criteria identified contribute to the knowledge of social
\end{abstract}

and economic sustainability in developing countries and aim to make those involved aware of the significance of their decisions in the different stages of the life cycle of construction projects.

Keywords Social Sustainability, Sustainable Development Goals, Equity, Green Building Rating Systems, Human Rights, Developing Countries

\section{Introduction}

How human beings have appropriated natural resources has had a great impact on the Earth's environmental systems, affecting people and nature. To address this situation the concept of sustainability arises, defined for the first time as "the capacity that the human system has developed to meet the needs of current generations without compromising resources and opportunities for growth and development of future generations" [1]. The definition of sustainability was accompanied with the recognition that it is useless to address environmental problems without a broader perspective that encompasses the factors that underpin global poverty and international inequality due to sustainable development is based on 
three pillars or spheres, commonly identified as the triple bottom line: social, economic and environmental [2]-[6], intricately linked and dependent [7], [8].

The construction industry, despite its important role in satisfying the needs of societies [9] and the economic growth of the countries [5], is the less sustainable activity on the planet [10]. Sustainable Building (SB) is a holistic process aiming to restore and maintain harmony between the natural and built environments and create settlements that affirm human dignity and encourage economic equity [11].

In the $80 \mathrm{~s}$, the evaluation or certification systems of sustainable building emerged, providing an effective framework to measure the environmental performance, integrating the principles of sustainable development in the building construction processes [12]. Currently, the Building Research Establishment Assessment Method (BREEAM) and Leadership in Energy and Environmental Design (LEED) are the most widespread evaluation systems for SB globally. BREEAM and LEED were created in countries with a high level of development (the United Kingdom and the United States, respectively) and, therefore, it responds to a cultural, economic, and social context very different from developing countries; where environmental issues accentuate but are a consequence of poverty, inequality, and lack of opportunities for the majority as well. As a result, the evaluation is strongly focused on the environmental component and for the social and economic component; it is limited to ensuring the physical and economic well-being of the user. In México, the voluntary standard NMX-AA-164-SCFI-2013 (NMX-164) was launched in 2013 as a first effort to introduce sustainability in the Mexican construction industry, but the categories and evaluation criteria show that it was taken from parameter existing systems and, therefore, replicating the same shortcomings. In the country with greater inequality of the OECD and $50 \%$ of the population in poverty, promoting sustainability separately from the social and economic component is completely unsustainable for present and future communities.

Preview research has addressed the Social Sustainability (SS) on the built environment [13]-[17], but there is a lack of knowledge about the impact of the stages of the life cycle of a building on the accomplishment of Sustainable Development Goals (SDGs) and human rights, particularly in the emerging economies, and a need for social sustainability guides for decision-makers. Assuming that all human activity has the responsibility and capacity to contribute to the achievement of the SDGs and the fulfilment of Human Rights, the purpose of this research was to identify socioeconomic sustainability criteria on developing countries, specifically México, and systematize them as a guide for practitioners in the stages of planning, design, and build, as frameworks on the sustainable architecture practice are an essential factor to ensure sustainable development in multiple dimensions [18].

\section{Literature Review}

\subsection{Social Sustainability (SS) in the Construction Industry}

The social pillar remains poorly defined in all areas of sustainable development [19],[20], due to its dynamic nature which changes over time [13] and depends on the site, the culture, and the people involved.

In the construction industry, SS aims to actively support the ability of current and future generations to create a healthy and liveable community by promoting equity, diversity, habitability, democracy, etc. [21] and includes criteria such as project declared general interests, safety, health of workers, leadership and knowledge management, local workers during construction, operation and maintenance, and training of workers [22]. Almahmoud \& Doloi [15] argues that the concept of SS in construction projects involves meeting the needs of industry, users, and neighbourhood communities. For Valdes-Vasquez et al. [23], SS in the building sector is the capacity to provide a good quality of life by creating healthy and livable communities based on equity, diversity, connectivity, and democracy; on their research, they proposed a conceptual framework for the integration and evaluation of SS in construction projects containing six categories: stakeholder engagement, user considerations, team formation, management considerations, impact assessment, and place context. Olakitan Atanda [24] developed a set of 35 social criteria based on LEED and classified them into eight categories: social equity, environmental education, participation and control, social cohesion, health and safety, accessibility and satisfaction, cultural value, and physical resilience. For this research, SS in construction projects will be understood as the capacity of buildings to positively contribute to the SDGs, and human rights of persons directly or indirectly involved in any of the stages of the life cycle, considering that people in conditions of poverty and vulnerability are those who receive the strongest adverse effects of unsustainable lifestyles, consumption, and construction.

The SS not only promotes equal amenities among community residents but also the development of stronger and more robust communities [25]. According to Ahn, Pearce, Wang \& Wang [6], some of the social benefits of sustainability are: Improving the quality of life for individuals, and society as a whole, alleviating poverty, satisfying human needs; incorporating cultural data into development; optimizing social benefits; improving health, comfort, and well-being; having concern for inter-generational equity; minimizing cultural disruption; providing education services; promoting harmony among 
human beings and cultural capital; and understanding multidisciplinary communities.

\subsection{Social and Economic Sustainability and Assessment Systems}

Although in recent years the academy has addressed the SS more extensively, the certification systems have encountered difficulties in including it in the evaluation, leaving a gap that must be filled soon. Most green building assessment tools focus on environmental rather than sustainable development [26]-[28]. Illankoon, Tam \& Le [29] evaluated eight certification schemes, selecting LEED as the American representative and BREEAM as the representative of the European system. Following their research, they obtained the percentage of credits (points) granted for each of the sustainability areas. LEED allocates $18.03 \%$ and BREEAM $16.15 \%$ of its rating to the social sustainability criteria, and $0.82 \%$ and $2.31 \%$ respectively to the economic sustainability criteria.

Social items are associated with the user health, safety, and comfort components [30], well-being (thermal, visual and acoustic comfort, ventilation and safety), functionality (accessibility for people with disabilities, functional adaptability, and ease of maintenance), and protection (against fire, noise or earthquakes) [31], with very few points related to the community and other disadvantaged people. In 2018, LEED launched a Project Team Checklist for Social Impact [32] containing three categories: People and Participation, Community and Place, and Values in Action, and assigned pilot credits related to social equity; however, none of the existing evaluation systems fully develops the social sustainability, especially in developing countries [33].

Economic components are primarily focused on the financial costs and benefits [34] through the analysis of the Life Cycle Costs Analysis (LCC). "Green" projects benefit from the reduction of maintenance costs, water and electricity bills, increased user productivity, increased property value, and functional adaptability, but without a long-term commitment beyond the limits of the building. An economically sustainable construction project must seek the human well-being of all, the minimum consumption of scarce resources and their optimal allocation and distribution, and the universal access to the benefits of sustainability, thus contributing to environmental justice, poverty alleviation, and reduced inequities.

\subsection{Social Sustainability in Developing Countries}

In developing countries, projects are often not sustainable because the social aspect is not fully addressed [33],[35]. Social needs, community perceptions, cultural and political issues should prevail over the project development decisions in terms of the traditional cost-benefit analysis to fight against social injustice and exclusion as one of their priorities [15], given that the social, economic, and cultural contradictions are the true causes of their environmental problems [15],[11]. Construction projects create new relationships and interactions within a community, as well as between a community and nature, which has the potential to contribute to meeting the needs and challenges within the society, but there is a great need for operationalizing the SDGs targets and evaluate the indicators concerning the building industry [36],[14].

To contribute to the SS in developing countries, Pocock and et.al. [14] proposed nine processes to improve architects, engineers, builders, owners, and communities design and construction solutions: (1) Secure land in a way that is legal and sensitive to local culture (2) Engage the community in the entire life cycle of the project (3) Design with sensitivity to the local culture (4) Design for maximum efficiency of limited water supplies (5) Design locally sustainable systems for energy and thermal comfort (6) Design for the safety of the occupants by incorporating local codes while acknowledging international standards (7) Design projects that can be safely constructed by the local population (given training opportunities) (8) Build using locally understood construction methods (9) Build with locally sustainable and affordable materials.

\section{Research Methodology}

Older and very recent literature addresses social sustainability in the built environment, but there is relatively little that focuses on specific steps that owners of capital projects and design professionals can take [25],[20].

This research aims to contribute as a practical framework for practitioners in México, who wish to incorporate SS in their construction projects and contribute to achieving the SDG. The steps of the methodology are (1) diagnostic, (2) conceptual framework, (3) data collection, and (4) analysis.

\subsection{Diagnosis}

México is a country in North America, with a population of more than 126 million people, average schooling of 9.2 years, and an unemployment rate of $4.5 \%$ in January 2021, with a high percentage of people in informal employment (27.5\%) and sub-occupation (8.7\%) [37]. México's social issues have a deep complexity, which is nurtured and expressed in urban-architectural manifestations. The social base is at an impassable distance from the elites, originating dual cities, zoned by the economic income of its inhabitants; violence and insecurity have cracked traditionally strong community 
ties in a vicious circle in which this rupture contributes to increased insecurity in the public space [38]. The level of compliance with the SDG indicators in México is $65 \%$, with a particularly poor performance in SDG2, SDG8, SDG15, and SDG16, which correspond to No Hunger, Good jobs and economic growth, Life on Land, and Peace and justice, respectively, and declining performance in SDG10, reduced inequalities [39].

The priority problems were identified through a content analysis of the National Development Plan 2012-2018 [40], the 2018-2024 Nation Project [41], and the Economic Studies for México of the Organization for Economic Cooperation and Development [42]. The main problems are social or socio-economic, with poverty, inequality, and corruption, among others, being very relevant. The identified problems were classified according to the 17 Sustainable Development Goals, and the specific way in which the problem is related to the construction industry was synthesized, obtaining a list of questions (e.g., How could the planning, design, and construction of buildings promote gender equity?) for the interview guide.

\subsection{Conceptual Framework}

The questions obtained during the diagnosis were presented to experts in semi-structured interviews. The participants were five professionals from different disciplines whose professional practice or scope of work includes the attention of social problems, human rights, or the relationship of the human being with the built environment. In general, they are individuals recognized for their work, identified by their activism or opinion leadership.

Each interview provided valuable information to understand the phenomenon of social sustainability. The interviews were transcribed, and the answers were subject to analysis, categorized according to the stages of the life cycle of the projects, grouped by themes related to the SDGs and human rights, and refined to exclude the issues that belong to the usage stage, the environmental field (SDG6, SDG7, and SDG13), and those that are already evaluated by LEED or BREEAM certification systems.

The information was organized based on the 17 SDGs and their 169 targets [43], defined by the United Nations (UN) as an ambitious call for action to end poverty, protect the planet and ensure that all people enjoy peace and prosperity for 2030. All the signatory countries of the 2030 Agenda are committed to acting in favour of the SDGs, so the construction of buildings in México and the other countries should be aligned with global efforts. The criteria proposed by the interviewees correspond to the SDG1 No Poverty, SDG3 Good Health and Well-being, SDG5 Gender Equality, SDG8, Decent work and economic growth, SDG10 Reduced inequalities, SDG11 Sustainable cities and communities, SDG12 Responsible consumption and production, SDG15 Life on land, and SDG16 Peace, justice, and strong institutions. The criteria are also related to the human right to the land, the right to the city, the right to social security and decent work, and the right to a healthy environment. As a result, a list of 45 criteria was identified, distributed in the planning, design, and construction stage of projects.

\subsection{Data Collection and Analysis}

The conceptual framework was embodied in a 5-item Likert scale survey to identify the participants' perception of the relevance of each indicator, for the achievement of the SS in México and about the feasibility of that indicator being adopted by the construction industry in the socio-economic and cultural context of México. The first sample survey was piloted and reviewed by some participants, identifying opportunities for improvement, and adjusting as required. A final self-administered web-based survey was sent to architecture or engineering practitioners, academics, and students obtaining 79 answered surveys: 28 for the planning stage, 25 for the design stage, and 26 for the construction stage. The Cronbach's alpha factor for the data collected was 0.91 , 0.89 , and 0.94 , respectively.

\section{Findings and Discussion}

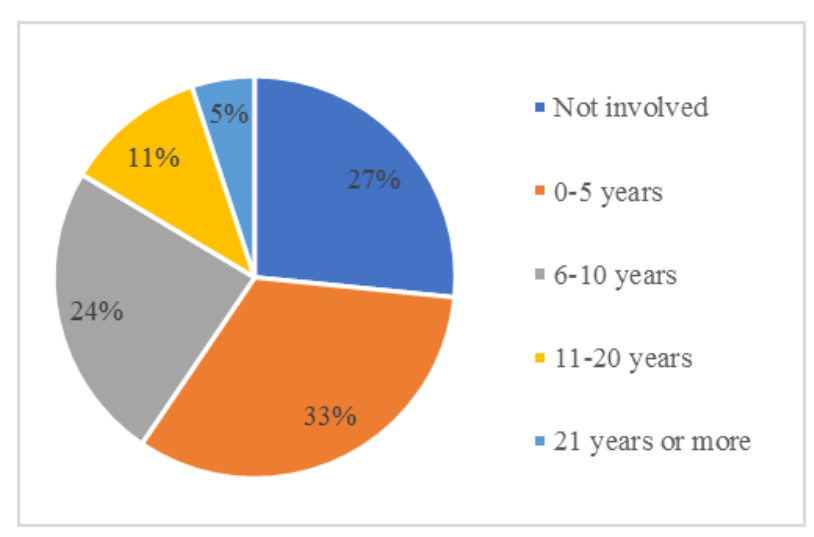

Figure 1. Participants' experience in sustainability or social issues

Survey participants were interviewed on their experience with social or sustainability issues (Figure 1) and their role in construction projects (Figure 2). Key informants were designers, builders or managers, and researchers or academics. A third of the participants reported having less than five years of experience in social or sustainability issues, and approximately $27 \%$ have not yet participated. The lack of experience is the common scenario in emerging economies, where most practitioners received professional training devoid of sustainability concerns [11], and a very strong barrier for the mass implementation of sustainable practices. Developing countries must invest in capacity building to ensure that 
future professionals more sustainably manage scarce resources and contribute positively to major social challenges.

The categories and criteria obtained in interviews were summarized in a framework as a guide for those participating in the planning (Table 1), design (Table 2), and construction (Table 3) phases of the projects. All topics were considered more relevant than feasible for achieving social sustainability in México, obtaining average values of $4.27,4.14$, and 4.80 for the relevance and $2.61,2.66$, and 2.2 for the feasibility in the planning, design, and construction stage, respectively.

The results obtained show that the construction of buildings can contribute to the SDGs, and policies or actions at the urban level would have greater impacts if each building constructed contributes its part. The criteria related to the right to the city and the reduction of inequalities are highly relevant on the planning, design, and build stage; actions on those issues would have effects on a wider scale, beyond the project limits, promoting the inclusion and contributing to the reconstruction of community ties. Given the close relationship between a building and its context, the guidelines presented contribute to transcending the building-centric approach [27], in which the building is perceived as isolated and it is subject to performance evaluations in energy and resources, instead of being seen as a producer of sustainability and an active part of an urban network.

At the planning stage "Do not dispossess land or evict indigenous or rural populations" (P01) was evaluated as the most relevant criterion (4.68), and as any abusive practice that violates the right to property must be eliminated. Since the possession of land is an important indicator for the eradication of poverty (SDG1). In this stage, policymakers have great potential to contribute socially if they consider the right to land and the right to the city, contained in SDG11. Project proponents often, in subtle or obvious ways, strip away original settlers or human groups that do not match the intended users of the project. The eviction of indigenous groups to build on their lands, the proliferation of private residential units with controlled access in Latin American cities, urban colonialism, and gentrification are examples of practices contrary to social sustainability since they favour spatial segregation, social exclusion, and accentuate inequalities. The least feasible criteria were P05 "Mitigate the adverse social effects of gentrification", and P07 "Develop housing near work and recreation sites" since other interests and more complex processes such as urban growth and land speculation are involved.

At the design stage, "Specify durable and good quality materials, regardless of the user's socioeconomic status" (D18) was the most relevant criterion (4.68). Opportunities to contribute to SS are linked to the SDG5, SDG10, SDG11, and SDG12. Participatory, inclusive, and gender-sensitive design are more effective in achieving socially responsive buildings than traditional design methods, which may neglect the needs of some groups. In México, an issue of great social, political, and economic importance is the construction of affordable housing through loans for workers; aware of this, the research participants pointed to the need to project culturally adequate housing, to avoid replicating prototypes that do not respond to the orientation of the lots, and to and take care of the quality of the materials so that these models of housing do not become a second-class product. "Provide some benefit to the community" (D12) was considered the less feasible criterion (2.18).

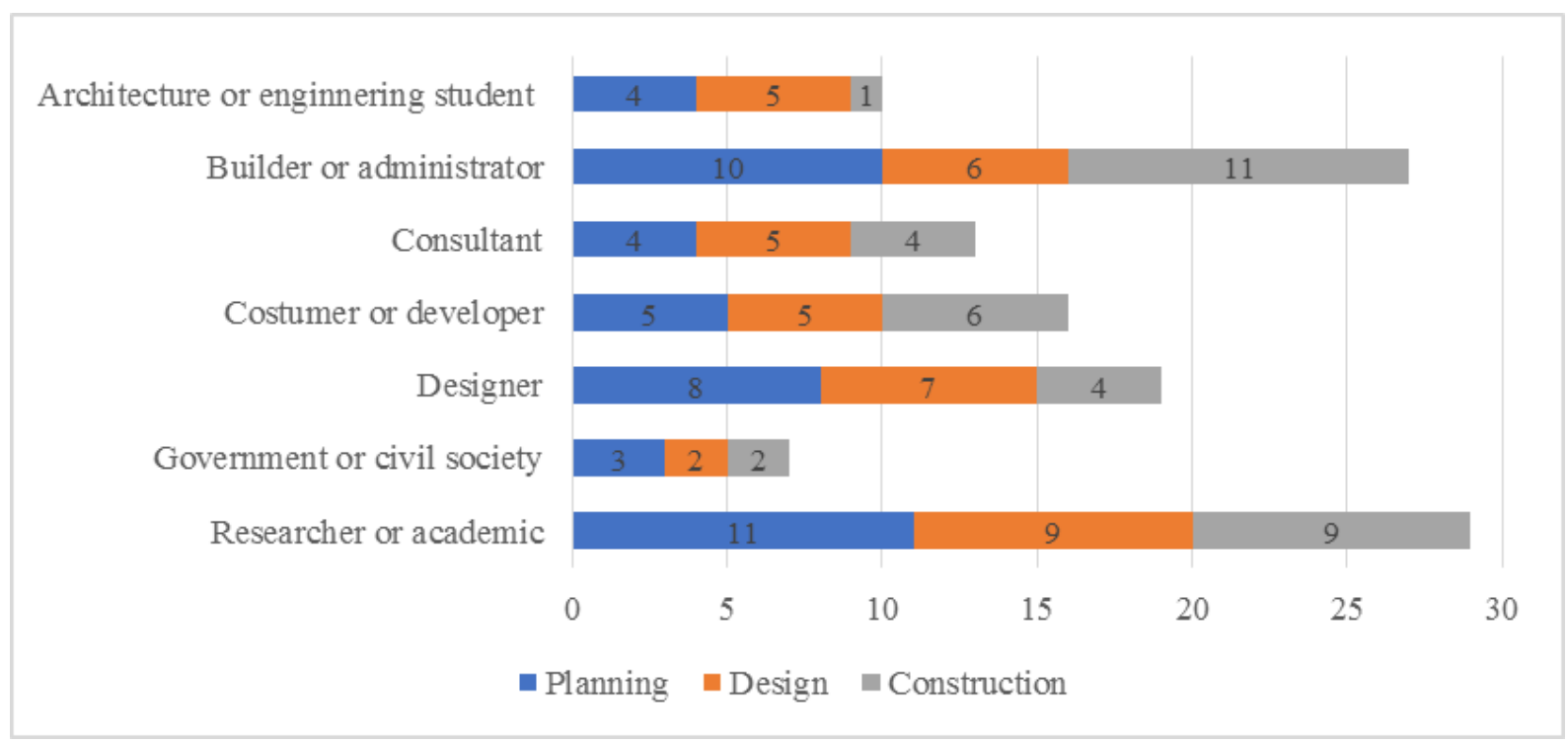

Figure 2. Role of Respondents in Construction Projects 
In the construction phase, the precautionary principle "Anticipate and correct possible negative effects on the environment" (B19) was the most relevant criterion (4.81). Responsible construction, which implies an ethical act towards employees, neighbours, passers-by, and the environment is still little applied in México, limited to the goodwill of the owners of the construction companies and without evaluating bodies.

Practitioners cannot ignore the pursuit of poverty eradication, access to health and education as a contribution to the achievement of the SDGs; the construction industry is the largest industrial employer in the world, and $74 \%$ of the employees are from low-income countries [11]; the issues related to social security and decent work (SDG8), as well as the measures aimed at improving the workers quality of life, have a great economic and social impact for many families. "Hire elderly or disabled adults" (B04) was the least feasible (1.69) of the construction stage and the entire questionnaire. Particularly in the construction stage, those involved have an important task in the fight against the barriers that offer low viability to social sustainability, since there is a significant gap between the relevance and the feasibility of applying the criteria included in the reference framework. (relevance mean 4.8 vs feasibility mean 2.2).

Table 1. SS Categories and criteria for the planning stage of construction projects

\begin{tabular}{|c|c|c|c|c|c|}
\hline & & & $\begin{array}{c}\text { SDG } \\
\text { Target }\end{array}$ & Relevance & Feasibility \\
\hline SDG1 & $\mathrm{P} 01$ & $\begin{array}{c}\text { Do not dispossess land or evict indigenous or rural } \\
\text { populations. }\end{array}$ & 1.4 & 4.57 & 2.71 \\
\hline \multirow{10}{*}{ SDG11 } & $\mathrm{P} 02$ & Avoid urban colonialism. & 11.3 & 4.36 & 2.46 \\
\hline & $\mathrm{P} 03$ & Avoid private residential with controlled access. & 11.3 & 4.25 & 2.57 \\
\hline & P04 & Develop less privileged urban areas. & 11.1 & 3.82 & 2.68 \\
\hline & $\mathrm{P} 05$ & Mitigate the adverse social effects of gentrification. & 11.a & 4.21 & 2.25 \\
\hline & P06 & Know and comply with the local Urban Development plans. & 11.a & 4.43 & 2.82 \\
\hline & P07 & Develop housing near services and recreation sites. & 11.a & 4.21 & 2.25 \\
\hline & P08 & $\begin{array}{c}\text { Seek adaptation to the natural, social, and cultural } \\
\text { environment. }\end{array}$ & 11.4 & 4.36 & 2.70 \\
\hline & P09 & Set objectives to cause a positive social impact. & - & 4.39 & 2.84 \\
\hline & $\mathrm{P} 10$ & Integrate with the neighbors and native settlers. & - & 4.39 & 2.50 \\
\hline & $\mathrm{P} 11$ & Promote the interaction between different income levels. & - & 3.89 & 2.43 \\
\hline SDG15 & $\mathrm{P} 12$ & Evaluate the vegetation before dismantling or clearing land. & 15.2 & 4.46 & 2.32 \\
\hline
\end{tabular}

Table 2. SS Categories and criteria for the design stage of construction projects

\begin{tabular}{|c|c|c|c|c|c|}
\hline \multicolumn{2}{|c|}{ DESIGN } & & $\begin{array}{c}\text { SDG } \\
\text { Target }\end{array}$ & Relevance & Feasibility \\
\hline SDG5 & D01 & Include the gender perspective in the design. & $5 . \mathrm{c}$ & 3.64 & 2.46 \\
\hline \multirow{5}{*}{ SDG10 } & D02 & Project for the accessibility of people with disabilities. & 10.2 & 4.52 & 3.36 \\
\hline & D03 & Avoid excluding or segregating any social group. & 10.2 & 4.52 & 3.16 \\
\hline & D04 & Make inclusive architectural representations. & - & 3.78 & 2.76 \\
\hline & D05 & Project spaces for family life and breastfeeding. & - & 3.94 & 2.40 \\
\hline & D06 & Include the needs of all users of the building. & - & 4.16 & 3.00 \\
\hline \multirow{9}{*}{ SDG11 } & D07 & Use participatory design strategies. & 11.3 & 4.00 & 2.28 \\
\hline & D08 & Design culturally appropriate housing. & 11.1 & 3.80 & 2.52 \\
\hline & D09 & Integrate the biocultural heritage into the design. & 11.4 & 4.08 & 2.24 \\
\hline & D10 & Consider the natural, human, and urban environment. & - & 4.44 & 2.80 \\
\hline & D11 & Promote porosity in public-private relief. & - & 3.56 & 2.52 \\
\hline & D12 & Provide some benefit to the community. & - & 4.24 & 2.18 \\
\hline & D13 & Nesting pedestrian access above the vehicle. & - & 4.12 & 2.32 \\
\hline & D14 & Design according to the orientation of each home. & - & 4.44 & 2.30 \\
\hline & D15 & Allow customization and adaptation to change of use. & - & 3.92 & 2.84 \\
\hline \multirow{3}{*}{ SDG12 } & D16 & Specify affordable, abundant, or local materials. & 12.2 & 4.48 & 3.34 \\
\hline & D17 & Design for the reduction of consumption in the use stage. & 12.5 & 4.42 & 2.94 \\
\hline & D18 & Specify durable and good quality materials & 12.5 & 4.68 & 2.54 \\
\hline
\end{tabular}


Table 3. Categories and criteria for the building stage of construction projects

\begin{tabular}{|c|c|c|c|c|c|}
\hline \multicolumn{2}{|c|}{ BUILDING } & & $\begin{array}{c}\text { SDG } \\
\text { Target }\end{array}$ & Relevance & Feasibility \\
\hline SDG3 & B01 & Promote reduction of employee vices & 3.5 & 4.42 & 2.19 \\
\hline \multirow[b]{2}{*}{ SDG5 } & B02 & Do not make distinctions by gender in hiring or salaries. & 5.5 & 4.31 & 2.73 \\
\hline & B03 & $\begin{array}{l}\text { Promote respectful treatment of female passers-by and } \\
\text { neighbors. }\end{array}$ & 5.2 & 4.35 & 2.54 \\
\hline \multirow{6}{*}{ SDG8 } & B04 & Hire elderly or disabled adults. & 8.5 & 3.58 & 1.69 \\
\hline & B07 & Privilege permanent hiring and offer training. & 8.5 & 4.31 & 2.38 \\
\hline & B05 & Grant social benefits to workers established in labor legislation. & 8.8 & 4.69 & 2.77 \\
\hline & B06 & Have safety and accident prevention procedures. & 8.8 & 4.69 & 2.87 \\
\hline & B08 & Support workers from distant populations. & - & 4.27 & 2.38 \\
\hline & B09 & $\begin{array}{c}\text { Employ local personnel, knowledge, and construction } \\
\text { techniques. }\end{array}$ & - & 4.35 & 3.50 \\
\hline \multirow{5}{*}{ SDG11 } & $\mathrm{B} 10$ & $\begin{array}{c}\text { Anticipate and correct possible negative effects on the } \\
\text { environment (precautionary principle) }\end{array}$ & 11.6 & 4.81 & 2.15 \\
\hline & B11 & Provide safe walkers and sidewalks. & 11.7 & 4.35 & 3.12 \\
\hline & $\mathrm{B} 12$ & Socialize projects with neighbors and users. & - & 4.31 & 2.02 \\
\hline & $\mathrm{B} 13$ & Avoid affectations to neighbors. & - & 4.42 & 2.62 \\
\hline & B14 & Address and resolve possible damages to neighbors. & - & 4.19 & 2.62 \\
\hline SDG16 & B15 & Do not consent to or promote corruption practices. & 16.5 & 4.77 & 2.27 \\
\hline
\end{tabular}

Some of the criteria on the proposed framework require special attention for having small feasibility values, despite being part of the current regulations, e.g., "Grant social benefits to workers established in labour legislation" (B05), and "Do not consent or promote corruption practices" (B15) and should be mandatory on any sustainability assessment system. In México, as in many other developing countries, the weak institutional capacity to verify conformity leaves gaps in the application of these basic premises. Another great challenge was found in the apparent contradiction between inclusion and security, in a country where more and more people want to surround themselves only with their peers to feel more secure. Without minimizing violence and insecurity in México, decision-makers must find creative solutions to this dilemma without excluding otherness.

The conceptual framework established by Valdés-Vasquez \& Klotz [23] has been in recent years the most complete reference when talking about SS in the built environment, and some of the processes it proposes are already part of international certification systems such as BREEAM or LEED. By comparing it with contributions from local experts, we reinforce the idea of Pocock [33], which ensures that many of the processes presented can be applied directly to the developing world, while others would be too ambitious. Still, we can find similarities in many of the topics covered by both frameworks, such as participatory design, socialization of projects with the community, attention to possible damage to neighbours, accident prevention, response to incidents of corruption, use of local personnel, support for workers, evaluation of social impacts, among others. The topics that are not addressed by Valdés-Vasquez \& Klotz [23] but emerged in the context studied are the dispossession or eviction of native settlers, urban segregation through the creation of closed urbanizations, integration of biocultural heritage, among others.

The proposed framework contrasts with the LEED Social Impact Category Checklist [32], which was launched during the analysis phase of this research. Even though most of the proposed indicators have a counterpart in the LEED guideline, others seem to be more specific to developing countries. The criteria related to the reduction of inequities, which is one of the most relevant findings of this research, and specifically the issues of urban segregation (interaction between people with different income levels, urbanizations with controlled access, porosity in the public-private relationship) are not part of the LEED document; neither are gender equity issues (wage differentiation, respectful treatment of transient women during construction), whose awareness has increased in recent years, or corruption, which costs México almost $9 \%$ of its GDP [44].

Regardless of the rating obtained in a green building certification system, a project should not be considered sustainable, if it was carried out despite social protests, involved some act of corruption or land grabbing, promotes "exclusivity" as market value, or deprive workers of social benefits.

\section{Conclusions}

In the construction sector, social sustainability is not yet 
fully understood, and the effects of construction projects on reducing poverty and inequality are highly underestimated. Stakeholders maintain a strong idea of sustainability as an entirely environmental issue, evidenced by survey participants assigning high importance to categories that have an environmental component, even when the social implication is unclear, or commenting on the need to include more environmental issues in the survey. In México, SS is assumed to be related solely to social housing or buildings in marginal areas, and many mega-development projects failed because the social component was ignored and people opposed it, which led to the cancellation on political grounds. Very often, projects are the result of ideas "from an office," away from the site and the culture. It is worse in countries with original indigenous peoples, who are usually treated as passive subjects of development.

The SS focused on the SDGs and human rights deserve further analysis among researchers and become a common concern for stakeholders and clients on construction projects, especially in developing countries. Integrating that overarching vision of SS into existing assessment systems would help move from "green building" schemes to "sustainability" schemes.

Future research could establish measurement objectives and procedures for each criterion, replicate the methodology on a different geographic or cultural context or integrate new topics as the knowledge and awareness of the SS increases.

Finally, the inclusion of social sustainability in a post-pandemic scenario becomes even more relevant, given that the extent to which humans are linked has been understood. Now more than ever, it will be necessary to learn to care for ourselves and otherness, to have the ability to develop buildings that are healthier for people and human relationships, and to smooth out the inequalities that have been accentuated in times of crisis.

\section{REFERENCES}

[1] G. H. Brundtland, "Our Common Future. Report of the World Commission on Environment and Development," 1987. doi: $10.1080 / 07488008808408783$.

[2] H. Said and L. Berger, "Future Trends of Sustainability Design and Analysis in Construction Industry and Academia," Pract. Period. Struct. Des. Constr., vol. 19, no. 1, pp. 77-88, Feb. 2014, doi: 10.1061/(asce)sc.1943-5576.0000181.

[3] A. L. Carew and C. A. Mitchell, "Teaching sustainability as a contested concept: capitalizing on variation in engineering educators' conceptions of environmental, social and economic sustainability," J. Clean. Prod., vol. 16, no. 1, pp. 105-115, 2008, doi: 10.1016/j.jclepro.2006.11.004.

[4] M. Boström, "A missing pillar? Challenges in theorizing and practicing social sustainability: Introduction to the special issue," Sustain. Sci. Pract. Policy, vol. 8, no. 1, pp. 3-14, 2012, doi: 10.1080/15487733.2012.11908080.

[5] M. Kucukvar and O. Tatari, "Towards a triple bottom-line sustainability assessment of the U.S. construction industry," Int. J. Life Cycle Assess., vol. 18, no. 5, pp. 958-972, 2013, doi: 10.1007/s11367-013-0545-9.

[6] Y. H. Ahn, A. R. Pearce, Y. Wang, and G. Wang, "Drivers and barriers of sustainable design and construction: The perception of green building experience," Int. J. Sustain. Build. Technol. Urban Dev., vol. 4, no. 1, pp. 35-45, 2013, doi: 10.1080/2093761X.2012.759887.

[7] J. W. S. Young, "A framework for the ultimate environmental index - Putting atmospheric change into context with sustainability," in Environmental Monitoring and Assessment, 1997, vol. 46, no. 1-2, pp. 135-149, doi: 10.1023/A:1005700321608.

[8] Francis, Encyclical Letter Laudato Sí. Tipografia vaticana, 2015.

[9] I. A. Rahman, A. H. Memon, and A. T. A. Karim, "Significant factors causing cost overruns in large construction projects in Malaysia," J. Appl. Sci., vol. 13, no. 2, pp. 286-293, Jan. 2013, doi: 10.3923/jas.2013.286.293.

[10]B. Edwards and P. Hyett, Guía básica de la sostenibilidad. Gustavo Gili, 2004.

[11]C. Du Plessis, Agenda 21 for Sustainable Construction in Developing Countries. CIB and UNEP by CSIR Building and Construction Technology, 2002.

[12] H. H. Ali and S. F. Al Nsairat, "Developing a green building assessment tool for developing countries - Case of Jordan," Build. Environ., vol. 44, no. 5, pp. 1053-1064, 2009, doi: 10.1016/j.buildenv.2008.07.015.

[13] M. R. Shirazi and R. Keivani, "Critical reflections on the theory and practice of social sustainability in the built environment-a meta-analysis," Local Environ., vol. 22, no. 12, pp. 1526-1545, 2017, doi: 10.1080/13549839.2017.1379476.

[14] N. B. Larsen and L. B. Jensen, "Current work on social sustainability in the built environment," IOP Conf. Ser. Earth Environ. Sci., vol. 225, no. 1, 2019, doi: 10.1088/1755-1315/225/1/012063.

[15]E. Almahmoud and H. K. Doloi, "Assessment of social sustainability in construction projects using social network analysis," Facilities, vol. 33, no. 3/4, pp. 152-176, Mar. 2015, doi: 10.1108/F-05-2013-0042.

[16] M. Farzanehrafat, A. Akbarnezhad, and P. Ghoddousi, "Analysis of different views towards social sustainability in construction," 32nd Int. Symp. Autom. Robot. Constr. Min. Connect. to Futur. Proc., 2015, doi: 10.22260/isarc2015/0113.

[17] S. Hendiani and M. Bagherpour, "Developing an integrated index to assess social sustainability in construction industry using fuzzy logic," J. Clean. Prod., vol. 230, pp. 647-662, 2019, doi: 10.1016/j.jclepro.2019.05.055.

[18] U. Emmanuel, C. B. Chukwuemeka, and K. C. Kalu, "Life cycle energy assessment (Lcea) approach: A prospect for sustainable architecture in developing countries," Civil Engineering and Architecture, vol. 8, no. 5, pp. 777-791, 
2020, doi: 10.13189/cea.2020.080505.

[19] M. Lehtonen, "The environmental-social interface of sustainable development: Capabilities, social capital, institutions," Ecol. Econ., vol. 49, no. 2, pp. 199-214, 2004, doi: 10.1016/j.ecolecon.2004.03.019.

[20]E. Eizenberg and Y. Jabareen, "Social sustainability: A new conceptual framework," Sustain., vol. 9, no. 1, 2017, doi: $10.3390 / \mathrm{su} 9010068$.

[21]A. Komeily and R. S. Srinivasan, "A need for balanced approach to neighborhood sustainability assessments: A critical review and analysis," Sustain. Cities Soc., vol. 18, pp. 32-43, Nov. 2015, doi: 10.1016/j.scs.2015.05.004.

[22]N. Dobrovolskienė and R. Tamošiūnienè, "An index to measure sustainability of a business project in the construction industry: Lithuanian case," Sustain., vol. 8, no. 1, pp. 1-14, 2016, doi: 10.3390/su8010014.

[23] R. Valdes-Vasquez and L. E. Klotz, "Social Sustainability Considerations during Planning and Design: Framework of Processes for Construction Projects," J. Constr. Eng. Manag., vol. 139, no. 1, pp. 80-89, 2013, doi: $10.1061 /($ asce)co.1943-7862.0000566.

[24] J. Olakitan Atanda, "Developing a social sustainability assessment framework," Sustain. Cities Soc., vol. 44, no. May 2018, pp. 237-252, 2019, doi: 10.1016/j.scs.2018.09.023.

[25] T. M. Toole and G. Carpenter, "Prevention through Design as a Path toward Social Sustainability," J. Archit. Eng., vol. 19, no. 3, pp. 168-173, 2013, doi: $10.1061 /$ (asce)ae.1943-5568.0000107.

[26] U. Berardi, "Clarifying the new interpretations of the concept of sustainable building," Sustain. Cities Soc., vol. 8, pp. 7278, 2013, doi: 10.1016/j.scs.2013.01.008.

[27]E. Conte and V. Monno, "Beyond the buildingcentric approach: A vision for an integrated evaluation of sustainable buildings," Environ. Impact Assess. Rev., vol. 34, pp. 31-40, 2012, doi: 10.1016/j.eiar.2011.12.003.

[28] A. Sharifi and A. Murayama, "A critical review of seven selected neighborhood sustainability assessment tools," Environ. Impact Assess. Rev., vol. 38, pp. 73-87, 2013, doi: 10.1016/j.eiar.2012.06.006

[29] I. M. C. S. Illankoon, V. W. Y. Tam, and K. N. Le, "Environmental, Economic, and Social Parameters in International Green Building Rating Tools," J. Prof. Issues Eng. Educ. Pract., vol. 143, no. 2, 2017, doi: 10.1061/(ASCE)EI.1943-5541.0000313.

[30] M. Hara, T. Nagao, S. Hannoe, and J. Nakamura, "New key performance indicators for a smart sustainable city," Sustain., vol. 8 , no. 3 , 2016, doi: $10.3390 /$ su 8030206 .

[31] J. Markelj, M. K. Kuzman, P. Grošelj, and M. Zbašnik-Senegačnik, "A simplified method for evaluating building sustainability in the early design phase for architects," Sustain., vol. 6, no. 12, pp. 8775-8795, 2014, doi: $10.3390 /$ su6128775

[32] USGBC, "LEED Project Team Checklist for Social Impact," 2018.

[33] J. Pocock, C. Steckler, and B. Hanzalova, "Improving Socially Sustainable Design and Construction in Developing Countries," Procedia Eng., vol. 145, pp. 288-295, 2016, doi: 10.1016/j.proeng.2016.04.076.

[34] A. J. Balkema, H. A. Preisig, R. Otterpohl, and F. J. D. Lambert, "Indicators for the sustainability assessment of wastewater treatment systems," Urban Water, vol. 4, no. 2, pp. 153-161, 2002, doi: 10.1016/S1462-0758(02)00014-6.

[35] J. O. Atanda and A. Öztürk, "Social criteria of sustainable development in relation to green building assessment tools," Environ. Dev. Sustain., vol. 22, no. 1, pp. 61-87, 2020, doi: 10.1007/s10668-018-0184-1.

[36] S. Janoušková, T. Hák, and B. Moldan, "Global SDGs assessments: Helping or confusing indicators?," Sustain., vol. 10, no. 5, pp. 1-14, 2018, doi: 10.3390/su10051540.

[37] Instituto Nacional de Estadística y Geografía, "https://www.inegi.org.mx/temas/empleo/.".

[38] G. Mendoza and J. A. González, "Reconstrucción del tejido social: una apuesta por la paz." Centro de Investigación y Acción Social por la Paz del Centro de Derechos Humanos Miguel Agustín Pro, México, p. 244 pp, 2016.

[39] COPS, Índice ODS 2019 para América Latina y el Caribe. Centro de los Objetivos de Desarrollo Sostenible para América Latina, 2020.

[40] SEGOB, "Plan Nacional de Desarrollo de México 2013 2018," Diario Oficial de la Federación, vol. 1, pp. 1-184, 2013.

[41] A. M. López Obrador, Proyecto De Nación. Presidencia de la República, 2018.

[42] OECD, "Estudios Económicos de la OCDE: México 2017," 2017. doi: $10.1787 / 9789264269040$-es.

[43]UNSD, "Global indicator framework for the Sustainable Development Goals and targets of the 2030 Agenda for Sustainable Development," Work Stat. Comm. Pertain. to 2030 Agenda Sustain. Dev., pp. 1-21, 2020.

[44] OECD, "OECD Integrity Review of Mexico. Taking a Stronger Stance against Corruption," 2012. doi: 10.1787/9789264273207-en. 